\title{
Optimization of Process Conditions for Microwave-assisted Flax Water Retting by Response Surface Methodology and Evaluation of its Fiber Properties
}

\author{
Dan Zhao, ${ }^{\mathrm{a}, \mathrm{b}}$ Hairui Ji, ${ }^{\mathrm{a}, \mathrm{b}}$ Renpeng Du, ${ }^{\mathrm{a}, \mathrm{b}}$ Qi Wang, ${ }^{\mathrm{a}}$ Wenxiang Ping,,${ }^{\mathrm{a}, \mathrm{b}}$ and \\ Jingping $\mathrm{Ge}^{\mathrm{a}, \mathrm{b}, *}$
}

\begin{abstract}
Microwave-assistance was used to increase the degumming efficiency in flax water retting. Different pre-soaking times, microwave times, and microwave power were investigated in this study. The relationships between degumming rate and process parameters were established via response surface methodology (RSM). The optimum process parameters were a pre-soaking time of $25.5 \mathrm{~h}$, a microwave time of $18.5 \mathrm{~min}$, and a microwave power setting of $570 \mathrm{~W}$. Under these optimal conditions, the degumming rate was $83.85 \% \pm 1.13 \%$, which was 1.33 times higher than that of natural hot water retting $(P<0.05)$. Moreover, the tensile properties and color of the resulting fibers showed that they had tensile properties similar to those of the natural hot water retting fibers. However, the color values for the natural hot water retting fibers were higher than those of the fibers treated with microwave-assisted flax water retting.
\end{abstract}

Keywords: Microwave; Flax; Retting; Optimization; Fiber properties

Contact information: a: Laboratory of Microbiology, College of Life Science, Heilongjiang University, Harbin, Heilongjiang, 150080 P. R. China; b: Engineering Research Center of Agricultural Microbiology Technology, Ministry of Education, Harbin, Heilongjiang, 150080 P. R. China;

* Corresponding authors: gejingping@126.com

\section{INTRODUCTION}

The flax (Linum usitatissimum L.) plant stem can be processed to produce flax fibers from its phloem, and it is known as the "fiber queen" (Ruan et al. 2015). Flax fiber is frequently used in textile, medical, and physical material fields due to its excellent properties, such as moisture retention, antimicrobial qualities, and air permeability (Zhao et al. 2016). Fibers attached to the stems with a close matrix contain hemicellulose, lignin, and pectin (Nair et al. 2016), and the process of acquiring pure fiber is called retting/degumming. In the retting process, relaxing the fibers from the plant phloem is performed using either mechanical or chemical methods (Nair et al. 2016). Various retting methods include enzyme retting, chemical retting, water retting or microbial retting, and mechanical retting, etc. (Nair et al. 2016). Enzyme retting demands a lot of water and chemicals that can contaminate the environment (Guo and Zhao 2010). Therefore, it is important to find a method that can decrease pollution, reduce cost, and dramatically enhance the fineness and cleanliness of fiber. Microwave-assisted retting has gained increased interest as a degumming method in industrial retting due to its low energy consumption and eco-friendly qualities. Microwave processing of flax could also lead to elasticity improvement, which is of exceptional interest for both composites and 
geotextiles applications ( $\mathrm{Li}$ et al. 2020). Application of microwave is feasible for flax retting, as it not only can save energy and reduce pollution but also shorten retting time.

Many factors influence the retting efficiency of the microwave-assisted flax water retting process. Response surface parameter (RSM) has been used to investigate the role of singular process parameters and the impact of their interactions when carrying out the responses (Hasni et al. 2017). Du et al. (2018) attempted to develop a mathematical model to increase the degumming efficiency, and it related the process parameters. This study aimed to explore the microwave-assisted retting process and improve the degumming efficiency of flax. Further, the fiber properties were also examined.

\section{EXPERIMENTAL}

\section{Materials}

Flax seeds were purchased from the Heilongjiang Academy of Agriculture Sciences (Heilongjiang, China) and grown in fields. After $110 \mathrm{~d}$, the flax stems were harvested and dried in preparation for retting.

\section{Methods}

\section{Microwave-assisted water degumming}

Flax stems were prepared by cutting them to equal lengths of $80 \mathrm{~mm}$. Non-retted flax stems weighing $3 \mathrm{~g}$ each were soaked in separate $100-\mathrm{mL}$ test tubes with flax bundle and tap water at the ratio of 1:20. The retting experiment lasted for $120 \mathrm{~h}$ at $30{ }^{\circ} \mathrm{C}$ (Zhao et al. 2016). The microwave-assisted/natural hot water degumming (retting) (Nair et al. 2015) was performed immediately after the pre-soaking for all samples (Zhao et al. 2018). The pre-soaked flax stems were subjected to microwave treatment in a microwave generator (Midea M1-L213C; Midea Group, Beijing, China). After degumming, the flax stems were placed in a ventilated place at room temperature until constant weight, and the fibers were obtained by manually peeling and removing impurities.

\section{Single factor experiment}

To evaluate the optimal degumming conditions for flax, the pre-soaking time, microwave time, and microwave power were studied using the 'one factor at a time approach' (keeping the rest factor constant) in order to estimate degumming rate in microwave-assisted water degumming system. To assess the optimum pre-soaking time, flax stems were water-soaked for times ranging from $0 \mathrm{~h}$ to $24 \mathrm{~h}$. The optimal microwave time for degumming rate was determined ranging from $7 \mathrm{~min}$ to $21 \mathrm{~min}$, keeping all other parameters at their optimum level. To evaluate the effect of microwave power on the degumming rate, experiments were conducted at 100, 200, 400, 550, and $700 \mathrm{~W}$, while keeping other parameters at optimum level. The rated power of the household microwave ovens is $700 \mathrm{~W}$. So one can choose different working positions during work, such as $20 \%$, $40 \%, 60 \%, 80 \%$, and $100 \%$. Therefore, the actual working power was estimated according to the rated power.

\section{Evaluation of degumming efficiency}

The degumming efficiency was measured with the Fried test. Fried test scores reflect the degree of degumming between plant phloem fiber and wood core fiber (Rognes et al. 2000). The degree of flax retting was calculated according to the average 
score (Zhang et al. 2000). Because Fried test scores can be subjective, the percentage change in weight loss of flax stem from non-retted to microwave-assisted water-retted flax phloem, i.e., the degumming rate, was also detected.

\section{Experimental design}

The system of microwave-assisted water retting involves interactions among several variables; thus, traditional methods were inefficient for optimizing the process (Ruan et al. 2015). The central composite design (CCD), which is the standard RSM, was employed for microwave-assisted water retting. Table S1 presents the experimental range of each variable and the levels of the independent variables. To obtain the optimum combination and influence of parameters on the microwave-assisted water retting, 20 experiments were performed in this reaction research, as considered necessary by the CCD (Table S2). The fit of the model was evaluated by means of two diagnostic residuals (Hasni et al. 2017). The test of statistical significance was performed on the total error criteria with a confidence level of $95 \%$. The fitted polynomial equation was as follows (Eq. 1),

$$
Y=\beta_{0}+\sum_{\mathrm{i}=1}^{\mathrm{k}} \beta_{\mathrm{i}} x_{\mathrm{i}}+\sum_{\mathrm{i}=1}^{\mathrm{k}} \beta_{\mathrm{ii}} x_{\mathrm{i}} x_{\mathrm{i}}+\sum_{\mathrm{i}<j} \sum \beta_{i j} x_{\mathrm{i}} x_{\mathrm{j}}
$$

where $Y$ is the response, $\beta_{0}, \beta_{\mathrm{i}}, \beta_{\mathrm{ii}}, \beta_{\mathrm{ij}}$ are constant coefficients, and $x_{\mathrm{i}}, x_{\mathrm{j}}$ are the coded independent variables or factors.

\section{Fiber properties}

According to the GB/T 17345-31 (2008) standard, the weight loss, strength, long fiber ratio (Hassan et al. 2004), and ratio variation of strength were determined. The color of the flax fibers was evaluated by the CIE $1976 L^{*}, a^{*}, b^{*}$ color space via the method of Saltzman (1981); $L^{*}, a^{*}$, and $b^{*}$ represent the whiteness/darkness, redness/greenness, and yellowness/blueness of the color of fibers, respectively. A fiber sample of approximately $20 \mathrm{~mm}$ in width and $10 \mathrm{~mm}$ thick was taken and put on a blank sheet of paper. The 5 to 6 points of each sample were chosen and determined via a tristimulus colorimeter, and the average values were recorded (Minolta Co., Ltd., Tokyo, Japan) (Ruan et al. 2015). Micrographic observation was performed by microscope (Olympus BX43; Olympus Corporation, Tokyo, Japan).

\section{Statistical analysis}

The data in this study were each obtained from three independent experiments, and the mean value \pm standard deviation $(\mathrm{SD})$ is presented. The experimental design was performed with the statistical software Design Expert (version 7.0.0, Stat-Ease, Minneapolis, MN, USA). In addition, JMP 9.0.2 (SAS Institute Inc., Cary, NC, USA) software was used to analyze statistical data.

\section{RESULTS AND DISCSUSSION}

\section{Effect of One Factor at a Time Experiments for Microwave-assisted Water Retting}

Effect of pre-soaking time

Pre-soaking time is a key factor that directly influences the retting efficiency of flax. Figure 1 depicts the pre-soaking time for the Fried test and degumming rate of flax. 
The result of the Fried test showed that the degree of degumming improved significantly $(\mathrm{P}<0.05)$ as pre-soaking time increased. Figure $1 \mathrm{~b}$ revealed that the degumming rate increased significantly as the pre-soaking duration increased $(\mathrm{P}<0.05)$. The degumming rate increased $10.92 \% \pm 0.23 \%$ when the pre-soaking time was increased from $4 \mathrm{~h}$ to 12 $\mathrm{h}$. However, changing the pre-soaking time from $12 \mathrm{~h}$ to $20 \mathrm{~h}$ produced an increase of only $3.03 \% \pm 0.07 \%$, and the degumming rate did not change after $20 \mathrm{~h}$. Similar results on pre-soaking time and flax degumming were found in previous research (Nair et al. 2016). However, Nair et al. (2013) reported that the maximum degumming efficiency was reached when flax stems were pre-soaked for $24 \mathrm{~h}$, which suggests a longer duration than that identified in this study.
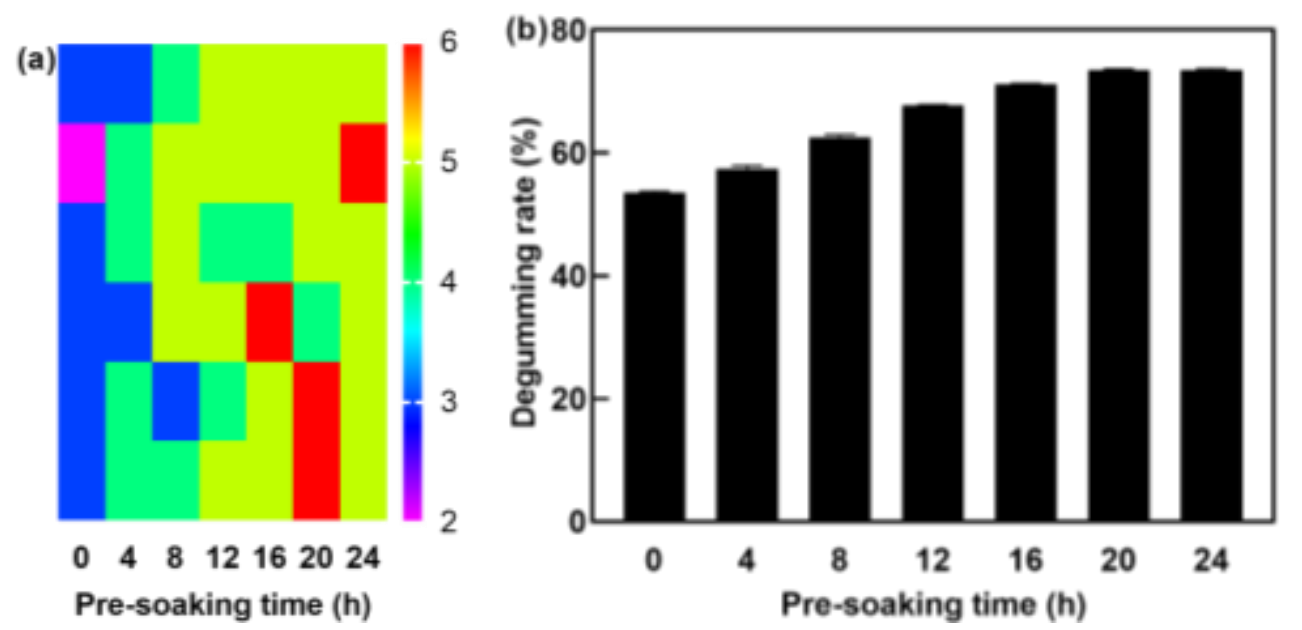

Fig. 1. Degumming efficiency of microwave-assisted water retting with different pre-soaking times: a) Fried test results, b) Degumming rate

\section{Effect of microwave time}

Research was also conducted to identify the optimum microwave time, and it was found that as the microwave time increased from $7 \mathrm{~min}$ to $15 \mathrm{~min}$, the Fried test scoring increased (Fig. 2a). Over $75 \%$ of its scoring on the Fried test was retained after 15 min of microwave.

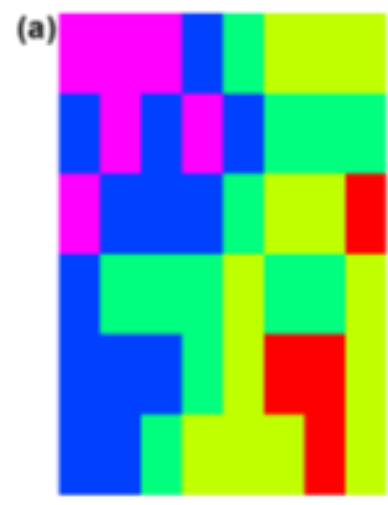

79111315171921 Microwave time (min)
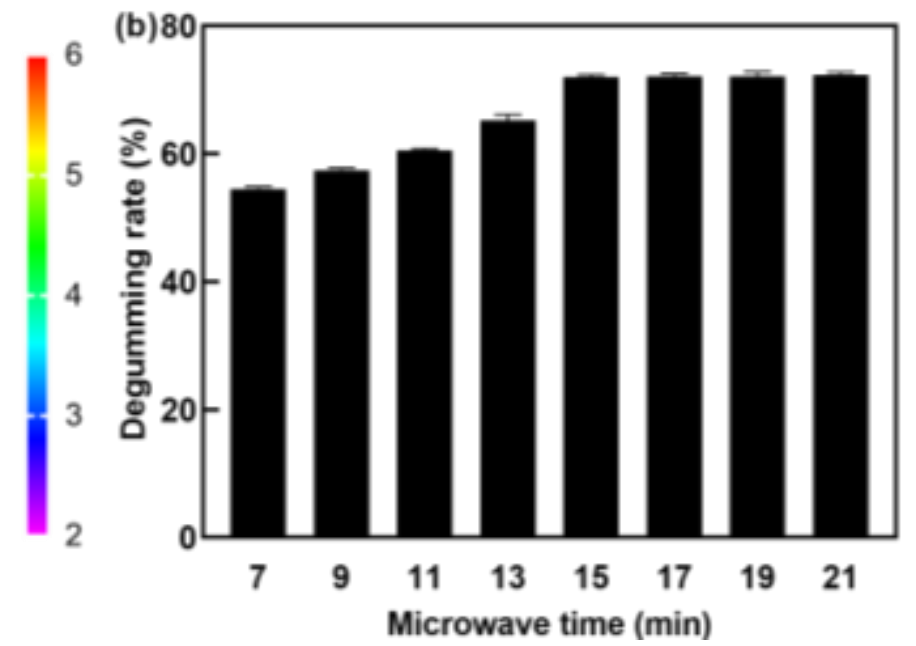

Fig. 2. Degumming efficiency of microwave-assisted water retting with different microwave times: a) Fried test results, b) Degumming rate 
Figure $2 \mathrm{~b}$ shows that the degumming rate significantly $(\mathrm{P}<0.05)$ increased as microwave time increased. This was due to the influence of microwave in damaging the strong pectin bonds that adhered to the flax fiber; this influence is called the "non thermal-effect" of microwave processing (De la Hoz et al. 2005). However, beyond 15 min, there was marginal additional change, and the change graph shows a plateau. All water was evaporated as microwave time increased and the over-heating of plant stems occurred, which could result in low quality fiber (Nair et al. 2016). Therefore, $15 \mathrm{~min}$ was selected as the microwave time with maximum degumming rate of $71.15 \% \pm 1.47 \%$. This result was similar to the results of Nair et al. (2013).

\section{Effect of microwave power}

The experiments were conducted by varying the microwave power. As shown in Fig. 3a, after reaching $550 \mathrm{~W}$ of microwave power, the Fried test scores were all above $75 \%$, which was higher $(\mathrm{P}<0.05)$ than the scores obtained from $100 \mathrm{~W}$ to $400 \mathrm{~W}$. Fried test scores were more stable under high power conditions, and approximately $100 \%$ of the scores remained after treatment at $700 \mathrm{~W}$. Figure $3 \mathrm{~b}$ revealed that the degumming rate significantly increased as microwave power increased $(\mathrm{P}<0.05)$. This was because the non-thermal and thermal influence of microwave power facilitated the hydrolysis of pectin (Tsubaki and Azuma 2011). The overall conversion increased to $74.31 \% \pm 2.06 \%$ when microwave power increased to $550 \mathrm{~W}$. The percentage increase in the degumming rate was $>70 \%$, which was significantly $(\mathrm{P}<0.05)$ greater than the degumming rates achieved with lower microwave power $(<400 \mathrm{~W})$. However, a further increase in microwave power resulted in a decrease of the percentage degumming rate to $73.17 \% \pm$ $1.24 \%$.

(a)

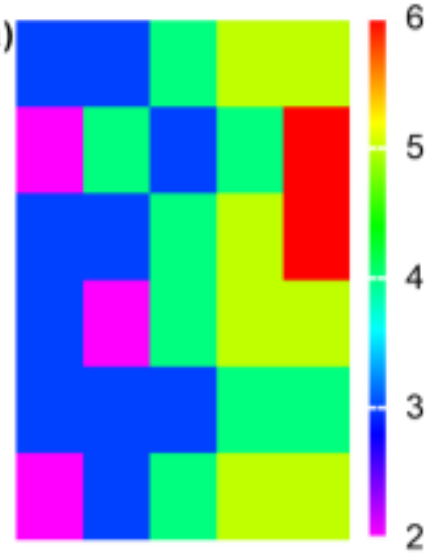

100200400550700

Microwave power (W)

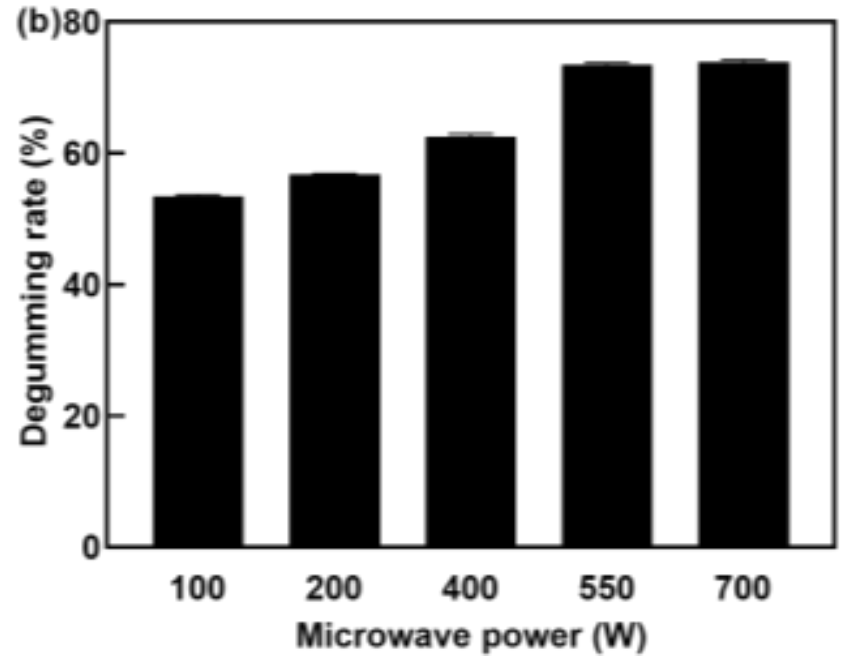

Fig. 3. Degumming efficiency of microwave-assisted water retting with different microwave power levels: a) Fried test scores, b) Degumming rate

\section{Optimization of Retting Process by CCD}

Optimization of the microwave-assisted retting process was carried out using 3 factors at three levels, which required a total of twenty runs. Table 2 shows the mean predicted and experimental values according to the quadratic model of pre-soaking time (A), microwave time (B), and microwave power (C) used to predict degumming rate. The analysis of variance (ANOVA) and regression analysis results of the model are shown in 
Table 1. Because of the lower $\mathrm{P}$ value and higher $\mathrm{F}$ value, the results indicated that the model was highly significant at the $95 \%$ confidence level. The "Lack of Fit F-value" of 0.1149, implies that the Lack of Fit is not significant relative to the pure error. Non-significant lack of fit is good for the model to fit. (Singh et al. 2018). The adjusted coefficient of determination (Adj $\mathrm{R}^{2}$ ) and the coefficient of determination $\left(\mathrm{R}^{2}\right)$ were 0.8561 and 0.9243 , respectively. The $\mathrm{R}^{2}$ of model was close to unity 1 , which indicated that the developed model of the degumming rate was representative of the process (Hasni et al. 2017). The value of adequate precision was 8.968, and the adequate precision obtained in this study was greater than 4.0, which indicated that this response had better precision and reliability (Ikrang and Umani 2019; Luo et al. 2019). In addition, the model was suitable for experimental relationships between the response and the variables (Anwar et al. 2017). The regression equation that describes the effects of the retting process variables on the degumming rate in terms of the actual values of the variable is given in Eq. 2:

Degumming rate $(\%)=77.44+8.12 \times \mathrm{A}+5.97 \times \mathrm{B}+8.51 \times \mathrm{C}+6.92 \times \mathrm{AB}$

$$
-10.77 \times A^{2}-11.19 \times B^{2}-6.38 C^{2}
$$

Table 1. Results of the Regression Analysis of the CCD

\begin{tabular}{|c|c|c|c|}
\hline Factor & Coefficient Estimate & F-value & $\mathrm{P}>|\mathrm{F}|$ \\
\hline Intercept & & 13.56 & $0.0002^{* \star}$ \\
\hline$A$ & 8.11 & 17.65 & $0.0018^{\star *}$ \\
\hline$B$ & 5.97 & 9.54 & $0.0115^{\star}$ \\
\hline C & 8.51 & 19.36 & $0.0013^{* *}$ \\
\hline$A^{*} B$ & 6.92 & 7.50 & $0.0209^{*}$ \\
\hline$A^{*} C$ & 1.26 & 0.25 & 0.6295 \\
\hline $\mathrm{B}^{*} \mathrm{C}$ & -1.41 & 0.31 & 0.6891 \\
\hline$A^{2}$ & -10.77 & 32.71 & $0.0002^{\star \star}$ \\
\hline$B^{2}$ & -11.19 & 35.32 & $0.0001^{\star \star}$ \\
\hline $\mathrm{C}^{2}$ & -6.38 & 11.48 & $0.0069^{\star *}$ \\
\hline Lack of Fit & & 3.18 & 0.1149 \\
\hline$=0.9243 \quad \mathrm{~A}$ & Adj $R^{2}=0.8561 \quad$ Adeq precision & & \\
\hline
\end{tabular}

Response surface plots and contour plots for expansion ratio and porosity were generated as a function of two independent variables, while other independent variables were kept at their centre point. Figure 4 shows the estimated response function and the effects of the independent variables (A, B, and C) on the dependent variables values. The convex surface plots indicated that there was a maximum predicted value of response variables. The results showed that the interactions among pre-soaking time and microwave retting time significantly affected the degumming rate $(P=0.0209<0.05)$ (Fig. 4). The degumming rate reached a highest value when the level of pre-soaking time, microwave time, and microwave power were $0.56,0.40$, and 0.69 , respectively. The optimum conditions for degumming rate predicted by the model were found as a pre-soaking time of $25.6 \mathrm{~h}$, a microwave time of $28.45 \mathrm{~min}$, and a microwave power of $569 \mathrm{~W}$. However, considering the actual operating conditions, the pre-soaking time, microwave time, and microwave power were adjusted to $25.5 \mathrm{~h}, 18.5 \mathrm{~min}$, and $570 \mathrm{~W}$, respectively. Nair et al. (2013) reported that flax has a better retting efficiency when soaked for $24 \mathrm{~h}$ and exposed to microwave retting for $20 \mathrm{~min}$. Based on these results, a 
maximum degumming rate of $83.85 \% \pm 1.13 \%$ was predicted by the software, which was 1.33 times higher than that predicted for natural hot water retting $(62.94 \% \pm 2.53 \%)(\mathrm{P}<$ $0.05)$.
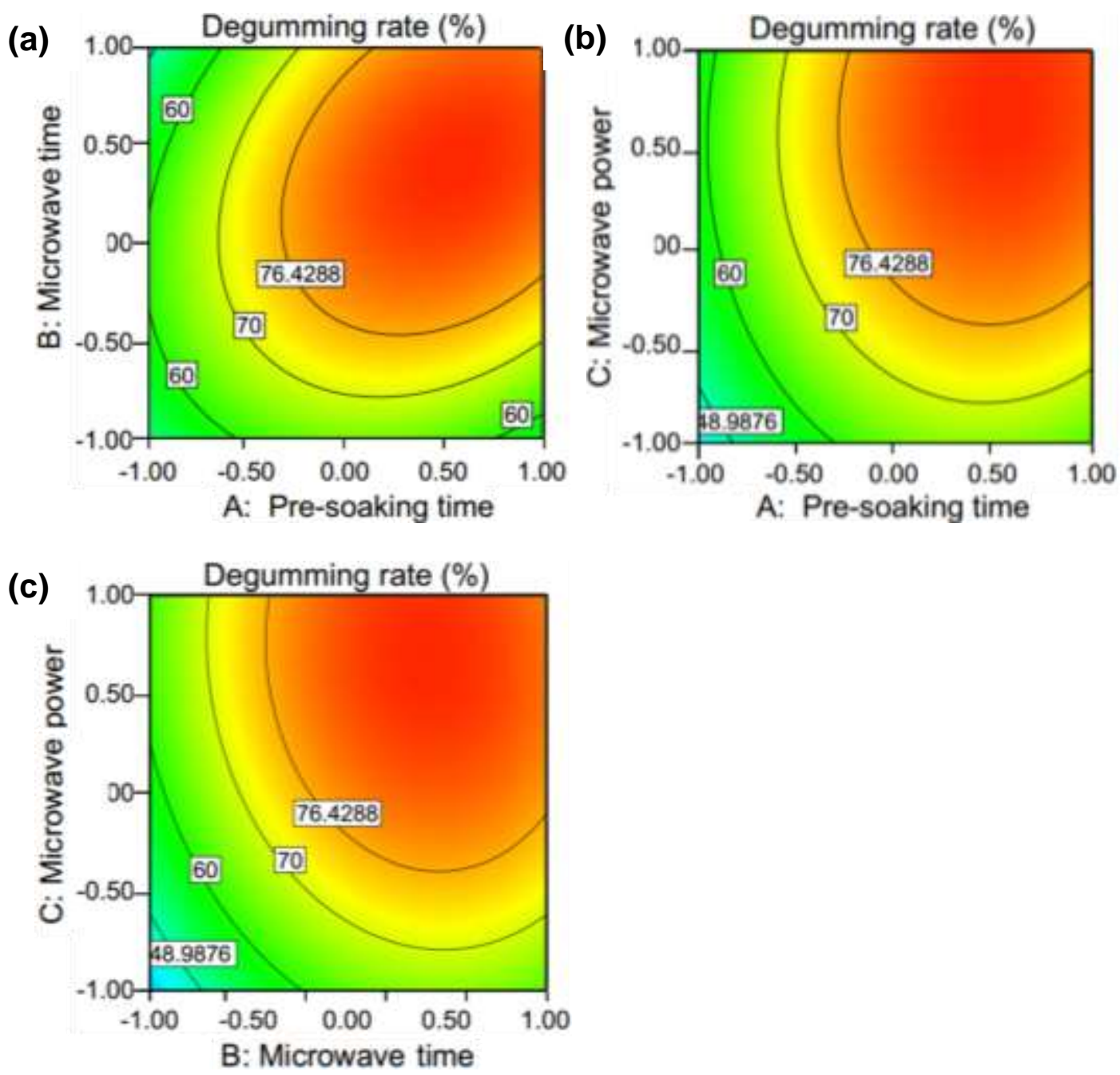

Fig. 4. The contour plots that show the effect of pre-soaking time and microwave time (a); pre-soaking time and microwave power (b); microwave time and microwave power (c) on the microwave-assisted water retting of flax

Bazaria and Kumar (2016) researched microwave-assisted water retting at the optimum retting conditions to test the adequacy of the model equation for predicting the response values. The results showed that the degumming rate of experimental values was $82.41 \% \pm 1.07 \%$, which was close to the predicted values $(83.85 \% \pm 1.13 \%)$, but higher than those reported by Ruan et al. (2015). Therefore, the model was suitable for assessing the behaviour of the retting process conditions of microwave-assisted water retting (Ikrang and Umani 2019).

\section{Properties of Fiber}

Weight loss of flax stem is another indicator of the degree of degumming. The results showed that the microwave-assisted water retting $(12.74 \% \pm 1.01 \%)$ led to a higher percentage of flax loss than natural hot water retting $(9.27 \% \pm 0.21 \%)$ (Table 2). This data were in line with the degumming rate results. It could be concluded that the 
application of microwave-assisted water retting resulted in more thorough degradation of pectin substances.

Table 2. Properties of Flax Fiber

\begin{tabular}{|c|c|c|c|c|c|c|c|}
\hline \multirow[t]{2}{*}{ Retting Method } & \multirow{2}{*}{$\begin{array}{l}\text { Degumming } \\
\text { Rate }(\%)\end{array}$} & \multirow{2}{*}{$\begin{array}{l}\text { Strength } \\
\text { (N) }\end{array}$} & \multirow{2}{*}{$\begin{array}{c}\text { Ratio } \\
\text { Variation } \\
\text { of Strength } \\
(\%)\end{array}$} & \multirow{2}{*}{$\begin{array}{l}\text { Long } \\
\text { Fiber } \\
\text { Ratio } \\
(\%)\end{array}$} & \multicolumn{3}{|c|}{ Color } \\
\hline & & & & & $L^{*}$ & $a^{*}$ & $b^{\star}$ \\
\hline $\begin{array}{c}\text { Microwave-assisted } \\
\text { Water Retting }\end{array}$ & $\begin{array}{c}82.17 \pm \\
1.14^{a}\end{array}$ & $\begin{array}{c}162.93 \pm \\
2.37^{a}\end{array}$ & $\begin{array}{c}27.28 \pm \\
1.03^{a}\end{array}$ & $\begin{array}{r}14.20 \\
\pm 0.65^{a}\end{array}$ & $\begin{array}{c}69.19 \\
\pm \\
1.04^{\mathrm{a}}\end{array}$ & $\begin{array}{c}3.65 \\
\pm \\
0.17^{a}\end{array}$ & $\begin{array}{c}24.08 \\
\pm \\
1.09^{a}\end{array}$ \\
\hline $\begin{array}{l}\text { Natural Hot Water } \\
\text { Retting }\end{array}$ & $\begin{array}{c}62.94 \pm \\
2.53^{b}\end{array}$ & $\begin{array}{c}162.78 \pm \\
3.19^{a}\end{array}$ & $\begin{array}{c}26.45 \pm \\
0.61^{a}\end{array}$ & $\begin{array}{c}13.71 \\
\pm \\
0.24^{a}\end{array}$ & $\begin{array}{c}64.18 \\
\pm \\
1.14^{\mathrm{b}}\end{array}$ & $\begin{array}{c}4.17 \\
\pm \\
0.23^{a}\end{array}$ & $\begin{array}{c}24.41 \\
\pm \\
1.33^{a}\end{array}$ \\
\hline
\end{tabular}

Different letters indicate significant $(P<0.05)$ difference among relative activity within the same column

The strength, ratio variation of strength, and long fiber ratio of flax showed no significant difference due to treatment by either microwave-assisted water retting or natural hot water retting, as the microwave did not change the coefficients of the property values of the flax. The tensile properties in this work were lower than the values reported by Zhao et al. (2018) but were within average ranges (Faruk et al. 2012). The properties of fibers can indicate their resistance to deformation under applied loads or stresses (Brindha et al. 2017). The whiteness of flax fibers exposed to microwave-assisted water retting was higher than those with natural hot water retting, and there was no significant different in the redness or yellowness of the fibers. The colors of the fibers were different because the dissolved pectin components degraded differently. Moreover, the nature hot water retting system included dissolved and settled contaminants and colored materials, which can influence the whiteness of fibers (Wang and Postle 2004). This demonstrated that the industrial application of microwave-assisted water retting would not be harmful (Nair et al. 2013). The microstructure pictures of fibers in Fig. 5 show that the fiber had a rougher, fibrillated fiber surface topography after treatment by natural hot water retting, which was because lignin, pectin, and other components were not completely removed (Xu et al. 2015).
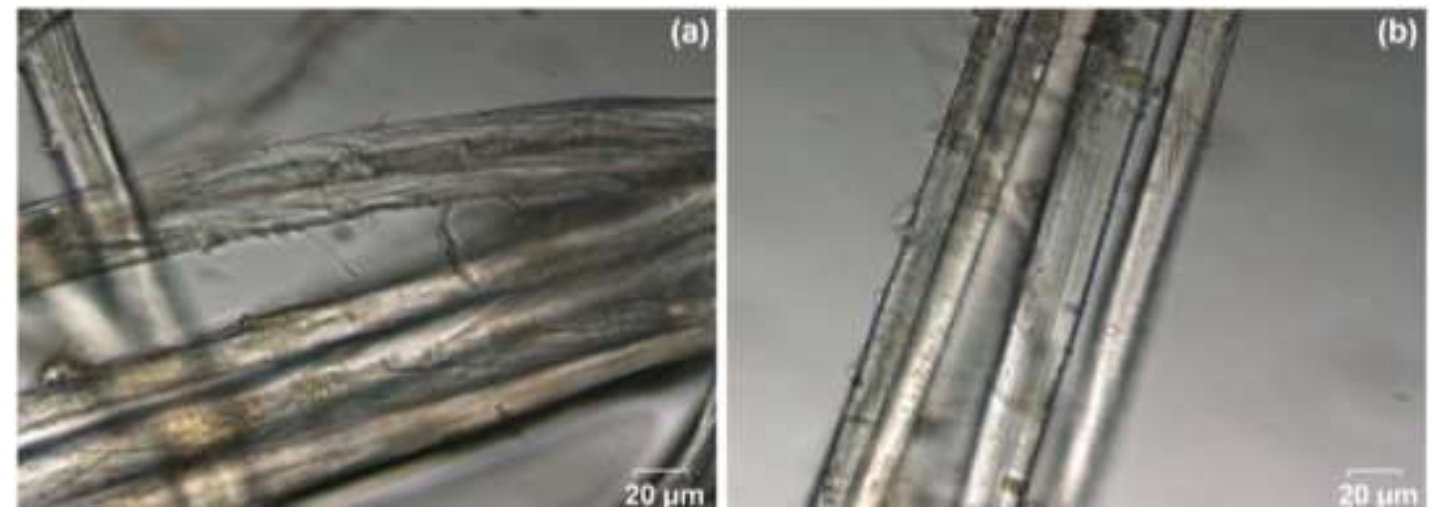

Fig. 5. Surface view of fibers via optical microscope of (a) natural hot water retted and (b) microwave-assisted retted 
In contrast, the fiber exposed to microwave-assisted water retting had a smooth surface. This result was in accordance with the results of others (Nair et al. 2014), which demonstrated the effectiveness of microwave-assisted water retting. This method almost completely removed pectin substances in the flax stem, which resulted in the production of pure, individualized fibres. In addition, microwave-assisted water retting resulted in a shorter retting duration than that of natural hot water retting. However, it may be lead to some water pollution and contamination arising from pre-soaking of the flax material. So, in the further research, the changes in color, total dissolved solids (TDS), $\mathrm{pH}$, conductivity quantity of sludge generated, total organic carbon (TOC), total organic nitrogen (TON), total organic phosphorus (TOP) and chemical oxygen demand (COD) of the pre-soaking water should be measured. Such research can help establish whether this type of retting can be useful for agriculture, industry or landscape development.

\section{CONCLUSIONS}

1. The degumming efficiency of flax was affected significantly by pre-soaking time, microwave time, and microwave power $(\mathrm{P}<0.05)$.

2. At optimum process parameters of $25.5 \mathrm{~h}$ of pre-soaking time, $18.5 \mathrm{~min}$ of microwave time, and $570 \mathrm{~W}$ of microwave power, the degumming rate for fibers exposed to microwave-assisted treatment was $82.41 \% \pm 1.07 \%$, which was 1.33 times higher than those treated with natural hot water retting $(\mathrm{P}<0.05)$.

3. Compared with natural hot water retting samples, the properties of fibers exposed to microwave-assisted treatment did not significantly change $(\mathrm{P}>0.05)$, and the color and surface of the fibers were significantly improved $(\mathrm{P}<0.05)$.

4. Microwave-assisted water retting resulted in a shorter retting duration than that required by nature hot water retting.

\section{ACKNOWLEDGMENTS}

This research was supported by the National Nature Science Foundation of China (31770538, 31770544, and 31270534), the Post Doctorate Foundation of Heilongjiang Province (LBH-Q18105) and the Fundamental Research Funds for Heilongjiang University, Heilongjiang Province (KJCX201921).

\section{REFERENCES CITED}

Anwar, M., Rasul, M. G., and Ashwath, N. (2017). "Production optimization and quality assessment of papaya (Carica papaya) biodiesel fwith response surface methodology," Energ. Convers. Manage. 156, 103-112. DOI: 10.1016/j.enconman.2017.11.004

Bazaria, B., and Kumar, P. (2016). "Optimization of spray drying parameters for beetroot juice powder using response surface methodology (RSM)," Journal of the Saudi Society of Agricultural Sciences 17(4), 408-415. DOI: 10.1016/j.jssas.2016.09.007 
Brindha, R., Narayana, C. K., Vijayalakshmi, V., and Nachane, R. P. (2017). "Effect of different retting processes on yield and quality of banana pseudostem fiber," J. Nat. Fibers 16(1), 58-67. DOI: 10.1080/15440478.2017.1401505

De la Hoz, A., Díaz-Ortiz, A., and Moreno, A. (2005). "Microwaves in organic synthesis. Thermal and non-thermal microwave effects," Chem. Soc. Rev. 34(2), 164-178. DOI: $10.1039 / \mathrm{b} 411438 \mathrm{~h}$

Du, R., Zhao, F., Pan, L., Han, Y., Xiao, H., and Zhou, Z. (2018). "Optimization and purification of glucansucrase produced by Leuconostoc mesenteroides DRP2-19 isolated from Chinese sauerkraut," Prep. Biochem. Biotech. 48(6), 465-473. DOI: 10.1080/10826068.2018.1466149

Faruk, O., Bledzki, A. K., Fink, H.-P., and Sain, M. (2012). "Biocomposites reinforced with natural fibers: 2000-2010," Prog. Polym. Sci. 37(11), 1552-1596. DOI: 10.1016/j.progpolymsci.2012.04.003

GB/T 17345-31 (2008). "Flax suctched line," Standardization Administration of the China, Beijing, China.

Guo, Y., and Zhao, S. (2010). "The application of ultrasonic in degumming for hemp," Applied Physics Research 2(1), 139-143. DOI: 10.5539/apr.v2n1p139

Hasni, K., Ilham, Z., Dharma, S., and Varman, M. (2017). "Optimization of biodiesel production from Brucea javanica seeds oil as novel non-edible feedstock using response surface methodology," Energ. Convers. Manage. 149, 392-400. DOI: 10.1016/j.enconman.2017.07.037

Hassan, A., Yahya, R., Yahaya, A. H., Tahir, A. R. M., and Hornsby, P. R. (2004). "Tensile, impact and fiber length properties of injection-molded short and long glass fiber-reinforced polyamide 6, 6 composites," J. Reinf. Plast. Comp. 23(9), 969-986. DOI: $10.1177 / 0731684404033960$

Ikrang, E. G., and Umani, K. C. (2019). "Optimization of process conditions for drying of catfish (Clarias gariepinus) using response surface methodology (RSM)," Food Science and Human Wellness 8(1), 46-52. DOI: 10.1016/j.fshw.2019.01.002

Li, C., Liu, S., Song, Y., Nie, K., Ben, H., Zhang, Y., Han, G., and Jiang, W. (2020). "A facile and eco-friendly method to extract Apocynum venetum fibers using microwave-assisted ultrasonic degumming," Ind. Crop. Prod. 151, 112443. DOI: 10.1016/j.indcrop.2020.112443

Luo, Y., Zhang, W., Li, J., Zhang, L., Zou, J., Hu, J., Yang, L., Xi, Y., and Liao, T. (2019). "Optimization of uranium removal from uranium plant wastewater by response surface methodology (RSM)," Green Process. Synth. 8(1), 808-813. DOI: 10.1515/gps-2019-0050

Nair, G. R., Kurian, J., Yaylayan, V., Rho, D., Lyew, D., and Raghavan, G. S. V. (2014). "Microwave-assisted retting and optimization of the process through chemical composition analysis of the matrix," Ind. Crop. Prod. 52(52), 85-94. DOI: 10.1016/j.indcrop.2013.10.007

Nair, G. R., Lyew, D., Yaylayan, V., and Raghavan, V. (2015). "Application of microwave energy in degumming of hemp stems for the processing of fibres," Biosyst. Eng. 131, 23-31. DOI: 10.1016/j.biosystemseng.2014.12.012

Nair, G. R., Rho, D., Yaylayan, V., and Raghavan, V. (2013). "Microwave assisted retting - A novel method of processing of flax stems," Biosyst. Eng. 116(4), 427-435. DOI: $10.1016 /$ j.biosystemseng.2013.10.004 
Nair, G. R., Singh, A., Kurian, J., and Raghavan, G. S. V. (2016). "Mathematical analysis of compound release during microwave assisted retting of flax stems," Biosyst. Eng. 150, 214-221. DOI: 10.1016/j.biosystemseng.2016.08.009

Rognes, H., Gellerstedt, G., and Henriksson, G. (2000). "Optimization of flax fiber separation by leaching," Cell. Chem. Technol. 34(4), 331-340.

Ruan, P., Raghavan, V., Gariepy, Y., and Du, J. (2015). "Characterization of flax water retting of different durations in laboratory condition and evaluation of its fiber properties," BioResources 10(2), 3553-3563. DOI: 10.15376/biores.10.2.3553-3563

Saltzman, M. (1981). Principles of Color Technology, Second Edition, John Wiley \& Sons, New York, NY, USA.

Singh, V., Belova, L., Singh, B., and Sharma, Y. C. (2018). "Biodiesel production using a novel heterogeneous catalyst, magnesium zirconate $\left(\mathrm{Mg}_{2} \mathrm{Zr}_{5} \mathrm{O}_{12}\right)$ : Process optimization through response surface methodology (RSM)," Energ. Convers. Manage. 174, 198-207. DOI: 10.1016/j.enconman.2018.08.029

Tsubaki, S., and Azuma, J. I. (2011). "Application of microwave technology for utilization of recalcitrant biomass," in: Advances in Induction and Microwave Heating of Mineral and Organic Materials, InTechOpen, Online, pp. 697-722. DOI: $10.5772 / 14040$

Wang, H. M., and Postle, R. (2004). "Improving the color features of hemp fibers after chemical preparation for textile applications," Textile Research Journal 74(9), 781-786. DOI: $10.1177 / 004051750407400906$

Xu, S., Xiong, C., Tan, W., and Zhang, Y. (2015). "Microstructural, thermal, and tensile characterization of banana pseudo-stem fibers obtained with mechanical, chemical, and enzyme extraction," BioResources 10(2), 3724-3735. DOI: 10.15376/biores.10.2.3724-3735

Zhang, J., Henriksson, G., and Johansson, G. (2000). "Polygalacturonase is the key component in enzymatic retting of flax," J. Biotechnol. 81(1), 85-89. DOI: 10.1016/s0168-1656(00)00286-8

Zhao, D., Pan, C., Ping, W., and Ge, J. (2018). "Degumming crude enzyme produced by Bacillus cereus HDYM-02 and its application in flax retting," BioResources 13(3), 5213-5224. DOI: 10.15376/biores.13.3.5213-5224

Zhao, D., Liu, P., Pan, C., Du, R., Ping, W., and Ge, J. (2016). "Flax retting by degumming composite enzyme produced by Bacillus licheniformis HDYM-04 and effect on fiber properties," J. Text. I. 108(4), 507-510. DOI: 10.1080/00405000.2016.1171482

Article submitted: April 3, 2020; Peer review completed: May 9, 2020; Revised version received: June 7, 2020; Accepted: June 8, 2020; Published: June 15, 2020.

DOI: $10.15376 /$ biores. 15.3.5859-5870 
APPENDIX

Table S1. Range of Different Factors Studied in the CCD

\begin{tabular}{|c|c|c|c|c|c|}
\hline \multirow{2}{*}{ Variable Quantity } & \multicolumn{5}{|c|}{ Level } \\
\cline { 2 - 6 } & -1.682 & -1 & 0 & 1 & +1.682 \\
\hline A: Pre-soaking Time (h) & 3.2 & 10 & 20 & 30 & 36.8 \\
\hline B: Microwave Time (min) & 6.6 & 10 & 15 & 20 & 23.4 \\
\hline C: Microwave Power (W) & 297 & 400 & 500 & 600 & 668 \\
\hline
\end{tabular}

Table S2. Experimental Design and Results of the CCD

\begin{tabular}{|c|c|c|c|c|c|}
\hline \multirow{2}{*}{ Trial no. } & \multirow{2}{*}{$\mathrm{A}$} & $\mathrm{B}$ & $\mathrm{C}$ & \multicolumn{2}{|c|}{ Degumming Rate (\%) } \\
\cline { 5 - 6 } & & & & Estimated Value & Predicted Value \\
\hline 1 & -1 & 1 & 1 & $50.61 \pm 0.03$ & 45.97 \\
\hline 2 & 1 & -1 & -1 & $32.30 \pm 0.11$ & 33.29 \\
\hline 3 & -1.68 & 0 & 0 & $30.76 \pm 0.03$ & 33.38 \\
\hline 4 & 0 & -1.68 & 0 & $42.46 \pm 0.05$ & 35.91 \\
\hline 5 & 0 & 0 & 0 & $74.34 \pm 0.13$ & 77.45 \\
\hline 6 & 0 & 0 & 0 & $75.35 \pm 0.04$ & 77.45 \\
\hline 7 & 0 & 0 & 0 & $73.36 \pm 0.12$ & 77.45 \\
\hline 8 & 0 & 0 & 0 & $74.74 \pm 0.11$ & 77.45 \\
\hline 9 & 1 & 1 & 1 & $85.45 \pm 0.17$ & 61.63 \\
\hline 10 & 1 & 1 & -1 & $66.76 \pm 0.01$ & 34.18 \\
\hline 11 & -1 & 1 & -1 & $41.13 \pm 0.02$ & 30.40 \\
\hline 12 & -1 & -1 & 1 & $49.47 \pm 0.12$ & 56.76 \\
\hline 13 & -1 & -1 & -1 & $30.17 \pm 0.06$ & 45.17 \\
\hline 14 & 0 & 1.68 & 0 & $43.66 \pm 0.11$ & 77.45 \\
\hline 15 & 0 & 0 & -1.68 & $42.21 \pm 0.13$ & 55.50 \\
\hline 16 & 0 & 0 & 0 & $84.55 \pm 0.10$ & 77.45 \\
\hline 17 & 1 & -1 & 1 & $52.45 \pm 0.02$ & 60.76 \\
\hline 18 & 0 & 0 & 0 & $83.26 \pm 0.15$ & $71.11 \pm 0.12$ \\
\hline 19 & 0 & 0 & 1.68 & $57.74 \pm 0.14$ & \\
\hline 20 & 1.68 & 0 & 0 & & \\
\hline
\end{tabular}

